\title{
COVID-19 and the Creeping Necropolitics of Crimmigration Control
}

\author{
Robert Koulish ${ }^{1,2}$ (D)
}

check for updates

Citation: Koulish, Robert. 2021. COVID-19 and the Creeping Necropolitics of Crimmigration Control. Social Sciences 10: 467. https: / / doi.org/10.3390/ socsci10120467

Received: 1 December 2021 Accepted: 1 December 2021 Published: 6 December 2021

Publisher's Note: MDPI stays neutral with regard to jurisdictional claims in published maps and institutional affiliations.

Copyright: (C) 2021 by the author. Licensee MDPI, Basel, Switzerland. This article is an open access article distributed under the terms and conditions of the Creative Commons Attribution (CC BY) license (https:/ / creativecommons.org/licenses/by/ $4.0 /)$.
MLAW Programs, University of Maryland, College Park, MD 20742, USA; rkoulish@umd.edu
Department of Government and Politics, University of Maryland, College Park, MD 20742, USA

The COVID-19 pandemic has had a drastic impact on migration and migrants and immigration policies worldwide. Considering that over 250 million people have contracted the disease globally, includingin that figure 5.1 million deaths, there is hardly any part of the globe which has escaped government attempts to control migration in order to stop the spread of disease. Migrants, particularly those in detention, have been the most susceptible to COVID-19, and the most vulnerable to punitive COVID-19 politics, as the pandemic has had a disproportionate impact on institutionalized populations (Turcotte 2021).

Governments have responded to COVID-19 with border closures, travel bans, and other disruptions to migrant flows world-wide. At first, these initial immigration responses were generally accepted as reasonable attempts to mitigate the spread of disease (BanulescuBogdan et al. 2020; O'Brien 2021). However, the obvious fact is that viruses are not easily deterred by border walls or gated ports of entry. Short of stopping the return of nationals or at least quarantining them upon arrival to their home country, deploying public health protocols for contact-tracing, social distancing, and supplying masks, immigration authorities can achieve little to mitigate the spread of the infectious disease.

This Special Issue was inspired by the observation that migration controls flourished despite their inability to mitigate the spread of the Coronavirus. More than 750,000 people in the U.S. died after former President Trump first imposed COVID-19 inspired travel restrictions in March 2020. Many countries including the U.S. have since deployed migration penologies as a pretext to deter and punish new arrivals. Migrant penologies include anti-immigrant narratives intended to distract public opinion from the governments' own inabilities to remain ahead of the virus and redirect growing public anxiety towards immigrants as a convenient and regrettably hate-filled scapegoat.

The Special Issue contends with this pretext, in particular the pattern of how, why and when (and also, who) migration-centered COVID-19 policies ended up punishing rather than protecting immigrants through this public health nightmare. The Issue follows a recent book Maartje van der Woude and I co-edited called Crimmigrant Nations: Resurgent Nationalism and the Closing of Borders (Koulish and van der Woude 2020). The book was published about a week before the virus hit and governments shut down borders around much of the world in spring 2020. The articles in this Special Issue grapple with regulating crimmigration in relation to COVID-19, following along similar lines as to those in our book. That is to say, the articles in this Special Issue draw direct and indirect reference to three overlapping theories of migration control catalogued by Weber and McCulloch (2018). The theories are (1) crimmigration, (2) new penology, and (3) enemy penology. These theories help understand efforts to criminalize, securitize, and even terrorize immigrants in the name of protecting public safety and national security. As much as these theories interrogate the harsh regulation of migrant life through controls, COVID-19 directs attention to the necropolitics of migration control.

Crimmigration highlights the how of migration and border control, with a focus on legal form and process (Weber and McCulloch 2018; Stumpf 2006). Crimmigration drew its name from immigration policies enacted during the 1990s that perversely blurred 
the distinctions between crime control and immigration law. This occurred within an immigration law framework that dilutes due process and other procedural safeguards for immigrants while importing a robust carceral regime to immigration driven by the private prison complex.

Second, new penology responds to the why of migration and border control, to bring immense and sophisticated technologies to bear on migration and migrant communities. Technologies are purposed to control mobility and migrants through surveillance, detention, and removal (Weber and McCulloch 2018). A deeper dive connects mobility and migration control to larger shifts in political economy and the preservation of white elite hegemony (Miller 2019; Mercille 2011; Xenakis and Cheliotis 2020; Koulish and van der Woude 2020). New penology scholars, including van der Woude and Van Lersel, have in this Issue applied Jonathan Simon's Governing Through Crime thesis to migration control (Bosworth and Guild 2008). Governing through migration rather than governing migration shifts from regulating borders through entry and exit requirements, to regulating migrants through punitive bordering, detention, and harsh expulsions (Koulish and van der Woude 2020).

Third, enemy penology describes the who and when of migration and border control (Krasmann 2007; Weber and McCulloch 2018). It starts with a triggering event (the when) by a perceived enemy (the who). The event could be real (the 9/11 catastrophe or COVID-19) or manufactured (migrant caravans heading to the U.S. border in 2018; border closures to asylum seekers in Poland during COVID-19). Similarly, the who can be real or imagined. The triggering event rationalizes the deployment of august state power: border closures, travel bans, and state of emergency declarations, followed by military deployment. Migrant control mechanisms also include surveillance, detention, and removal. What turns executive power into august power is the combination of vast resource allocation with the lack of accountability and oversight from the courts or legislature. Almost always, the who is constituted by people of color: Muslims after 9/11 and AAPI during COVID-19.

Anti-immigrant narratives inform public opinion against immigrants and increase their vulnerability to attack from governments and right-wing vigilantes. Throughout immigration history, pandemics have been associated with exclusionary narratives against foreigners. Nation-states have sought to blame racial and ethnic minorities as responsible for human suffering internally for the purpose of diverting attention from the governments' own failure to protect its people. Scapegoating the ethnic and racial 'other' during pandemics provides a through line for anti-immigration discourses generally. The anti-Asian message in Trump's "china-virus" tweets for example can be traced back to Justice Fields' opinion referring to unassimilable alien hordes in the Chae Chan Ping case in 1889. Chinese were similarly blamed for spreading smallpox at the end of the 19th century, and more recently for SARs, just as Muslims were put on alert by the moral panic generated after September 11.

This Special Issue features a critical examination of administering migration penologies and crimmigration during Covid in a variety of countries in Europe, Australia, and the United States. The reader will notice that the countries' immigration responses to COVID-19 can be pinpointed along a loosely defined spectrum of punitiveness from abolition to necropolitics. Where they fall on the spectrum is due to a variety of factors beyond the scope of this Special Issue, but include the following: governing type (democratic versus authoritarian) and currents of liberal rights versus ethnonationalism. A country's willingness to engage punitive migrant penologies presumably indicates the salience of ethnonationalism and authoritarianism within a country's politics. Were there a law and policy that foreshadows a country's embrace of authoritarian ethnonationalism, it is immigration law and policy. The through-line is to structural racism, overwhelming executive power, and a pre-Warren Court era application of due process and other procedural rights.

My reading of the authors shows government responses were the most punitive in the United States, U.K., Greece, and Poland, showing, for example, the rising tide of ethnonationalism in the U.S. The Dutch response was more temperate, hence coinciding with its social democratic institutions. The article on Spain highlights temporary abolition. 
The U.S. case under former President Trump, written by three authors, highlights the former President's infatuation with authoritarian and ethnonationalist power grabs at immigrants' expense, garnering a spot at the punitive side of this sliding scale. Poland's right leaning regime (Bartyzel 2021) similarly steers a punitive turn, and the U.K.'s Brexit policies and fancy with Trumpism helps explain its punitive governing of crimmigration under COVID-19.

The contributions in this Special Issue should be read through the three theoretical frames: The how of crimmigration, which focuses on law and policies that are intendedly punitive or punitive in their effects. Migrant penologies focus on the administration of the technologies of power regulating the life of migrant populations. The why is to render migrant populations productive or docile. The who and when that enemy penologies responds to occupy a similar terrain but on securitization rather than criminalization grounds. Enemy penologies helps authorities to distinguish Syrians and Belarusians at the Polish border (the former as enemy), for example, and ban Muslims from U.S. airports (Klaus 2020; Koulish and van der Woude 2020).

Additionally is the necropolitics of crimmigration informed by COVID-19. As much as the three theories contend with the harsh regulation of migrant life, necropolitics addresses the regulation of migrant death. The concept borrows from Giorgio Agamben's Homo Sacer (Agamben 1998) and was coined by Achille Mbebe (2019). Mbebe describes necropolitics as "the power to manufacture an entire crowd of people who specifically live at the edge of life, or even on its outer edge-people for whom living means continually standing up to death ... (where) Nobody even bears the slightest feelings of responsibility or justice ..." (Mbebe 2019, pp. 37-38).

The concept helps to understand how in the thick of the pandemic governments refused to release immigrants from detention facilities, creating as an outcome the utterly avoidable risk of exposing large numbers of densely populated immigrants to COVID-19. Additionally, it describes the dehumanizing efforts to stigmatize, injure, and humiliate "those not considered to be one of us" (Mbebe 2019, p. 58). The necropolitics of crimmigration in the U.S. is associated with two Trumpian COVID-19 era enforcement practices: Migrant Protection Protocols (MPP), forcing asylum seekers back into Mexico, and Title 42, expelling undocumented immigrants on public health grounds. MPP and Title 42 highlight the government's indifference to "small doses" of death at the border. As Human Rights First recently reported, "When the U.S. government delivers people seeking safety to danger in Mexico, through Title 42, or MPP, they face unimaginable violence and persecution" (21 October 2021). In sum, the concept of necropolitics sheds light on efforts to govern migrants through COVID-19.

In the following, I briefly introduce the authors' arguments in order from the least punitive to most punitive country case studies, from abolition to cruelty for its own sake.

In the first article, Coronavirus and Immigration Detention in Europe: The Short Summer of Abolition? Jose Angel Brandariz and Fernandez-Bessa provide a case study of Spain drawing on "the multi-scalar nature of mobility governance" in the EU. The case study of the national policy agenda in Spain demonstrates it as an outlier in the E.U. crimmigrationverse. Whereas most countries used COVID-19 to combat immigrants, Spain introduced an abolitionist detention stance during the summer of 2020. Spain closed detention centers and released immigrants as Spanish courts interpreted international law. Additionally, the authors contend with the harsh realities in other detention centers in the Canary Islands and elsewhere under Spanish control to show Spain's position is far from ideal. Still, the authors take a lessons-learned approach to consider a future in Europe that minimizes detention.

Maartje van der Woude and Van Lersel in Governing Migration through Covid-19? Dutch Political and Media Discourse in Times of a Pandemic, borrow Jonathan Simon's (Simon 2007) new penology framework to frame empirical research into the Dutch response to COVID-19 using crimmigration. Following Simon, the authors analyze the governing through migration thesis using key factors from Simon's original theory, the proximity and proportionality of government response to the (COVID-19) problem. They find the 
Netherland's anti-immigration response is more temperate than some but more punitive than many EU countries.

In The Exceptional Becomes Everyday: Border Control, Attrition and Exclusion from Within, Regina Serpa compares crimmigration in the U.K. and the Netherlands. Of the two, the UK has the more coercive crimmigration environment, compared to the Netherland's spiriting a more temperate approach to immigrants in the time of COVID-19. The gist of Serpa's analysis focuses on 'welfare penalism', in which local U.K. housing authorities played 'soft cop' during COVID-19 by reporting homeless migrants to immigration authorities for removal.

In Dealing with the 'Crimmigrant Other' in the face of a Global Public Health Threat: A Snapshot of Deportation during Covid-19 in Australia and New Zealand, Henrietta McNeill addresses the tension between using crimmigration to fight COVID-19 and using COVID19 to exacerbate crimmigration. She focuses on the challenge of detaining and deporting immigrants in the face of the pandemic to discover in both Australia and New Zealand that governments prioritized the constructed securitized threat over the real threat posed by COVID-19.

Byron Villagomez Moncayo's article, The Stigma of Being Venezuelan in Ecuador in the Pandemic Context, frames the crimmigration analysis through the tension between the Constitutional provision opening the door to immigrants and national security restrictions influenced by the United States. The arrival of Venezuelan refugees pushed Ecuador into the punitive camp of harsh xenophobic exclusions.

In Covid-19 as the New State-Of-The-Art in Crimmigration Milieu, Joanna Tsiganou, Anastasia Chalkia, and Martha Lempesi focus on Greece's crimmigration in the age of COVID-19. The authors' analysis shows similarities to the Polish situation but highlighting techniques of control over asylum seekers unprotected from COVID-19. Here the Greek state failed to provide for the public health of asylum seekers, specifically concrete screening. By caging asylum seekers in dystopian camps where social distancing is impossible, and excluding them from vaccines and COVID-19 tests, the authors identify new crimmigrant identities under the rubric of public health discrimination.

Witold Klaus in The Porous Border Woven with Prejudices and Economic Interests: Polish Border Admission Practices in the Time of Covid-19, shows how COVID-19 accentuates the harsh realities of crimmigration on migrants. As Klaus reports, Poland's COVID-19 response is "more of the same, only worse." Poland opened and closed the border in pursuit of economic and political interests rather than in response to the public health crisis. Borders were closed to asylum seekers following dictates of xenophobia to prevent entrance to Muslim asylum seekers, but were issuing protocols to accommodate Belarusian refugees, while also opening the border to migrant workers despite the pandemic. Klaus shows that the Polish asylum policy preferred to be governed by old demons rather than public health concerns and followed demands of the Polish labor market for migrant workers over concerns for the pandemic. At the same time, and Belarus refugees were still denied access to protocols protecting them from COVID-19.

Of all the countries' responses to COVID-19 using crimmigration, U.S. policy under Trump was extreme. The border wall could not prevent 750,000 deaths. Although detention decreased from approximately 50,000 per day in 2019, to 19,000 per day in 2020, detainees were excluded from anti-COVID-19 protocols, and, as a result, about $10 \%$ of detainees tested positive, with nine reported deaths. Although detention decreased from approximately 50,000 per day in 2019 , to 19,000 per day in 2020 due to a federal court order, detainees were excluded from anti-COVID-19 protocols, and as a result about $10 \%$ of detainees tested positive, and there were nine reported deaths.

In On the Other Side of the Looking Glass: Covid-19 Care in Immigration Detention, Dora Schriro (Schriro 2009) provides an inside perspective on the U.S. detention system. Schriro is a former upper-level policy official inside DHS and the author of the "Schriro Report," a 2009 report that recommended decriminalizing detention through alternatives to detention and risk assessment. Unfortunately, ICE systematically undermined many of the 
report's recommendations, positioning Schriro to take a more critical stance towards U.S. detention policy.

In Detained During a Pandemic: Human Rights Behind Locked Doors, Justine Stephanelli's take is similarly critical of U.S. detention during COVID-19. Stephanelli frames detention using human rights to show how far U.S. detention has strayed from human rights norms, and even fails much lower domestic standards still designed to mitigate substandard conditions and outright abuse. Stephanelli examines access to health care and counsel, two important tools to advance overriding public health concerns during the pandemic.

In The House is on Fire but We Kept the Burglars Out: Racial Apathy and White Ignorance in Pandemic-Era Immigration Detention, Wenjie Liao, Kim Ebert, Joshua Hummel, and Emily Estrada make use of content analysis to discover how activists and direct stakeholders responded to the COVID-19 crisis. Activists and stakeholders were represented by the ACLU, ICE, and the private prison industry (CoreCivic and GEO group). The article is framed by the recognition that crises have the potential and carry opportunities for radical change. They query the responses of stakeholders in the business of detaining immigrants for signs of new approaches to detention. To follow the thread of the Special Issue, the authors show that the health of detainees are not much of a concern for ICE during COVID19. Additionally, ICE manufactured an alternative storyline featuring "COVID fraud" which adds to the growing list of enemy penologies.

The articles in this Special Issue show how the pandemic exacerbated the perversions of crimmigration to the immigrants' harm. Perversions that flipped a civil process into a largely privatized criminal juggernaut and that endeavors to fill detention beds and contain migrants by the thousands in closely confined spaces.

The authors share the intent to unpack the criminalization of migration. Their contributions help to understand how different countries governed migrants through COVID-19. This introduction is in part intended to guide the comparison along a heuristic scale of punitiveness from abolition to regulating death.

It is my hope that this issue contributes to a growing movement of activist scholarship pointing away from the punitive narratives and techniques that deny justice under immigration law, and towards a process that is fair and respects human dignity. As much as COVID-19 shows governments manipulating crisis as a tool to exacerbate migrant controls, it also reveals a yearning for an alternative paradigm that applies due process and fair procedures to immigrants and provides them with safe routes to membership status in their new destination.

Funding: This research received no external funding.

Conflicts of Interest: The author declares no conflict of interest.

\section{References}

Agamben, Giorgio. 1998. Homo Sacer: Sovereign Power and Bare Life. Stanford: Stanford University Press.

Banulescu-Bogdan, Natalia, Meghan Benton, and Susan Fratzke. 2020. Coronavirus is Spreading across Borders, But It Is Not a Migration Problem. Washington: Migration Policy Institute.

Bartyzel, Dorota. 2021. Anti-Migrant Stance helps Boost Polish Ruling Party's Popularity. Available online: https:/ /www.bloomberg.com/ news / articles/2021-09-14/anti-migrant-stance-helps-boost-polish-ruling-party-s-popularity (accessed on 23 November 2021).

Bosworth, Mary, and Mhairi Guild. 2008. Governing Through Migration Control: Security and Citizenship in Britain. British Journal of Criminology 48: 703-19. [CrossRef]

Klaus, Witold. 2020. How Does Criminalization Unfold in Poland? Between Securitization Introduced to Polish Migrants by its Europeanization and Polish Xenophobia. In Koulish and van der Woude, Crimigrant Nations: Resurgent Nationalism and the Closing of Borders. New York: Fordham University Press.

Koulish, Robert, and Maartje van der Woude. 2020. Crimmigrant Nations: Resurgent Nationalism and the Closing of Borders. New York: Fordham Press.

Krasmann, Susanne. 2007. The Enemy on the Border: Critique of a Programme in Favor of the Preemptive State. Punishment $\mathcal{E}$ Society 9: 301-18.

Mbebe, Achille. 2019. Necropolitics. Durham: Duke University Press.

Mercille, Julien. 2011. Violent Narco-Cartels or U.S. Hegemony? The Political Economy of the 'war on drugs' in Mexico. Third World Quarterly 32: 1637-53. [CrossRef] 
Miller, Todd. 2019. Empire of Borders: The Expansion of the US Border Around the World. Brooklyn: Verso.

O'Brien, Michelle. 2021. Suppression, Spikes, and Stigma: How Covid-19 will Shape International Migration and Hostilities towards It. International Migration Review 55: 640-59. [CrossRef]

Schriro, Dora. 2009. Immigration Detention Overview and Recommendations. Washington: DHS.

Simon, Jonathan. 2007. Governing Through Crime: How the War on crime Transformed American Democracy and Created a Culture of Fear. Oxford: Oxford University Press.

Stumpf, Juliet. 2006. The Crimmigration Crisis: Immigrants, Crime, and Sovereign Power. International Organizations Law Review 56: $356-420$.

Turcotte, Maura. 2021. Virus Cases are Surging at crowded Immigration Detention Centers in the U.S. NYT. September 6. Available online: https:/ / www.nytimes.com/2021/07/06/us/covid-immigration-detention.html (accessed on 21 November 2021).

Weber, Leanne, and Jude McCulloch. 2018. Penal Power and Border Control: Which Thesis? Sovereignty, Governmentality, or the Pre-emptive State. Punishment \& Society 21: 496-514.

Xenakis, Sappho, and Leonidas K. Cheliotis. 2020. The Trumping of Neoliberal Penality? Trump's Presidency and the Rise of Nationalist Authoritarianism in the United States. In Koulish and van der Woude, Crimigrant Nations: Resurgent Nationalism and the Closing of Borders. New York: Fordham University Press. 